\title{
Docking studies of 1,5-disubtituted tetrazoles analogs of the anticancer drug imatinib as probable inhibitors of the ABL kinase and the T315I mutant kinase ${ }^{\dagger}$
}

\author{
Abel Suárez-Castro ${ }^{*}$, Carlos J. Cortes-García ${ }^{2 *}$, Rocío Gamez-Montaño ${ }^{3}$ and Luis Chacón- \\ García $^{1 *}$. \\ 1 Laboratorio de Diseño Molecular, Instituto de Investigaciones Químico Biológicas, Universidad \\ Michoacana de San Nicolás de Hidalgo. Ciudad Universitaria, C.P. 58033, Morelia, Michoacán, México; \\ lchacon@umich.mx \\ 2 Laboratorio de Investigación y Desarrollo, Apotex, API Toluca, Av. Industria Automotriz 301 Col. Zona \\ Industrial Toluca, C.P. 50071, Toluca, Edo. Mex., México; quimcharly@gmail.com \\ 3 Departamento de Química, División de Ciencias Naturales y Exactas, Universidad de Guanajuato, Noria \\ Alta S/N, Col. Noria Alta, C.P. 36050, Guanajuato, Gto., México; rociogm@ugto.mx \\ * Correspondence: quimcharly@gmail.com; Tel.: +52(722)2757007 ext 199 \\ + Presented at the title, place, and date. \\ Academic Editor: name \\ Received: date; Accepted: date; Published: date
}

\begin{abstract}
A docking studies of a set of several 1,5-disubstituted tetrazoles (1,5-DS-T) compounds to find potential inhibitors of the Abelson tyrosine-protein kinase (ABL kinase) and the mutated ABL kinase T315I were conducted by using Lamarckian genetic algorithms as search algorithms in Autodock4. Bayesian calculations were performed, and specificity (Sp) and sensitivity (Se) values as well as positive predicted values (PPVs) and negative predicted values (NPVs) were calculated using a set of 99 active ligands and 385 decoys for ABL kinase from the DUD database. RMSD values were calculated between the X-ray crystallographically determined coordinates of the ligands in the complexes of ligand with the ABL kinase and with T315I ABL kinase resistant to imatinib. The predicted results showed the importance of the interactions of the protein with halogens present in some of these 1,5-DS-T ligands. In conclusion, the results suggest that eight novel 1,5-DS-T compounds were identified to be effective inhibitors of ABL kinase.
\end{abstract}

Keywords: 1,5-DS-T, ABL kinase, Docking.

\section{Introduction}

Chronic myelogenous leukemia (CML) is a human disease characterized by a translocation between chromosomes 9 and 22 into the c-abl locus of chromosome 9 and the bcr region of chromosome 22 [1]. Its incidence is 2 per 100000 each year and the common age of diagnosis of the disease is 50 to 55 [2]. ABL tyrosine kinases constitute a family of proteins with the best-conserved branches of the tyrosine kinases. There are two types of ABL tyrosine kinases: ABL1, which is involved in repairing damage to nuclear DNA, and ABL2, which binds actin and microtubules and is involved in cytoskeletal remodeling [3]. ABL genes have been observed' in a tumor gene in the Abelson murine lymphosarcoma virus [4]. Patients with CML express a BCR-ABL1 oncoprotein that enhances the tyrosine kinase activity of the cells, leading to down-regulation of cell growth and of replication-associated pathways such as those that use JAK/STAT, MAPK, RAS, RAF, JUNK and MYC [5]. Treatments for CML have included allogenic stem cell transplantation and the use of recombinant interferon-alpha, but the most effective treatments have involved the administration of tyrosine kinase inhibitors (TKIs) [6] Imatinib mesylate was the first TKI drug found to function 
against CML and to be well tolerated. Administration of this drug led to a complete cytogenetic response in 60 percent of cases and resulted in adverse events in less than 6 percent of patients, whereas the complete cytogenetic response rate for recombinant-interferon has been reported to be only $41 \%$ [7]. The chemical optimization of imatinib [8] is shown in Figure 1.

a)<smiles>c1ccc(Nc2nccc(-c3cccnc3)n2)cc1</smiles>

c)<smiles>[R]C(=O)Nc1ccc(C)c(Nc2nccc(-c3cccnc3)n2)c1</smiles>

b)<smiles>[R]C(=O)Nc1cccc(Nc2nccc(-c3cccnc3)n2)c1</smiles>

Figure 1. Schematic representation of the moieties in imatinib (d). The color code is provided in the text

Here, a phenylamino derivative is the core structure of the lead compound (and shown in black in the figure). The addition of a 3-pyridyl group (in blue in panels a-d) to the 3'-position of the pyrimidine enhanced the activity. The amide group (in red in panels b-d) conferred activity against tyrosine kinases. Addition of a methyl group (in pink in panels $\mathrm{c}$ and d) abolished the undesirable protein-kinase-C inhibitory activity. Finally, inclusion of $\mathrm{N}$-methyl piperazine (in green in panel d) increased the solubility and oral bioavailability.

Type I, II and IV TKIs, including imatinib, nilotinib, dasatinib, bosutinib and ponatinib, have shown activity against Bcr-Abl and have been approved by the FDA (Figure 2), and about 36 compounds have been patented during the last 8 years [9]. Nevertheless, imatinib has been shown to lose its effectiveness against CML in up to $30 \%$ of patients during their first five years on therapy [10]. Here, various point mutations in the kinase domain of the Bcr-Abl protein (in particular between kinase domains) appear to cause such ineffectiveness of imatinib, by interfering with the interaction between the protein and the drug [10]. The mutations that most interfere with the drug activity are those at residues 255 and 315, with a mutation at residue 255 countering the inhibitory activity of nilotinib as well as of imatinib, and the T315I mutation (resulting in BCR-ABLT315I) interfering with the inhibitory activities of all TKIs [10]. 
<smiles>Cc1ccc(NC(=O)c2ccc(CN3CCN(C)CC3)cc2)cc1Nc1nccc(-c2cccnc2)n1</smiles><smiles>Cc1cn(-c2cc(NC(=O)c3ccc(C)c(Nc4nccc(-c5cccnc5)n4)c3)cc(C(F)(F)F)c2)cn1</smiles><smiles>Cc1nc(Nc2ncc(C(=O)Nc3c(C)cccc3Cl)s2)cc(N2CCN(CCO)CC2)n1</smiles><smiles>COc1cc(Nc2c(C#N)cnc3cc(OCCCN4CCN(C)CC4)c(OC)cc23)c(Cl)cc1Cl</smiles><smiles>Cc1ccc(C(=O)Nc2ccc(CN3CCN(C)CC3)c(C(F)(F)F)c2)cc1C#Cc1cnc2cccnn12</smiles>

Figure 2. FDA approved drugs that inhibit the ABL kinase

Many efforts are being expended to find inhibitors of ABL kinase that remain active even toward resistant mutations in T315I. One good example is the compound PPY-A, which Zhou et al. [11] showed to have favorable interactions with and be a potential inhibitor of the T315I ABL kinase. The PDB code: 4TWP [12] was used for the docking studies with the novel 1,5-DS-T compounds as ligands in this study.

The resistance showed for the ABL kinase is a good reason to explore the behavior of new compounds with different scaffolds to find therapeutics that are effective against BCR-ABL T315I. Here, predicted interactions and affinity using molecular docking studies of novel 1,5-disubstituted-1H-tetrazoles synthetized via the Ugi-azide reaction by Carlos Cortés et al. are presented [13]. these novel compounds are used since they include a fragment of imatinib (Figure 3). 

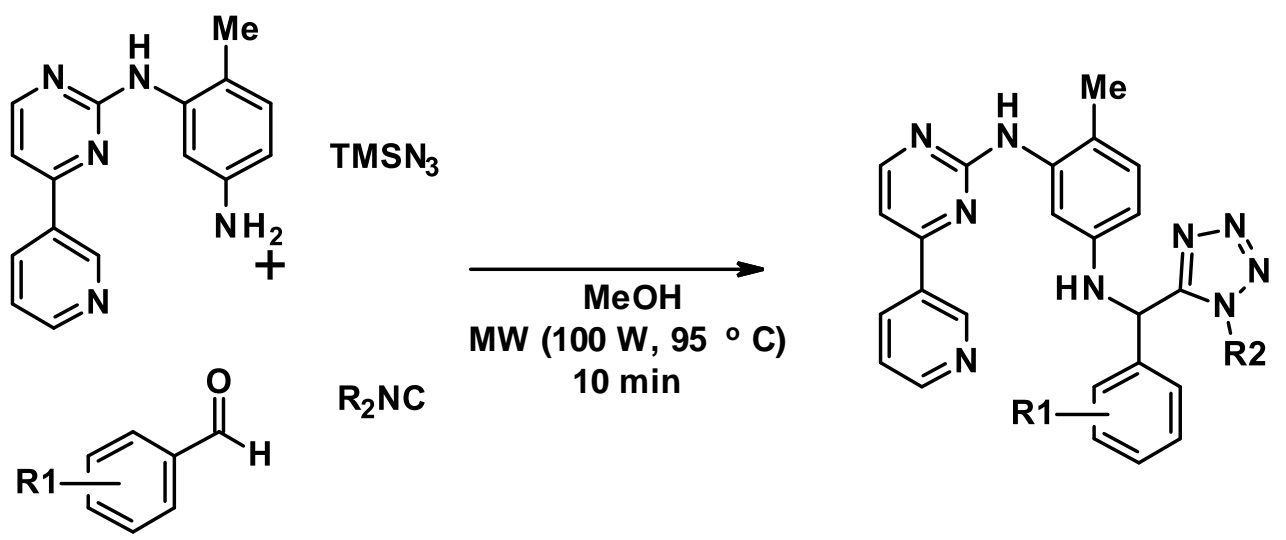

Figure 3. Overview of the synthesis of the new 1,5-DS-T compounds

\section{Materials and methods}

\subsection{Compounds data set}

To assess the docking protocol performance, the Bayesian theorem to 99 compounds known to be active against ABL kinase and 385 decoys for this kinase was applied. Both sets of compounds were retrieved from the Directory of Useful Decoys (DUD) [14] (www.dud.docking.org). Also, thirty-eight variants of 1,5-DS-T were synthetized by Cortés-Garcia et al. and used as exploration set of compounds, these structures are listed in table 1. The ligands AXI and JIN as reference crystallographic structures that came from the PDB codes used in this research (4TWP and 2HZI respectively) to compare the RMSD values after the docking calculations have been used.

\subsection{Computational experiments}

The 1,5-DS-T compounds synthetized by Cortes-García et al. were modeled as 2D structures with the software ChemBio Draw Ultra 12.0 and converted into 3D structures in MDL format. Their protonated states were then calculated using Chemicalize [15] (www.chemicalize.org), and these structures were then retrieved in a .mol file for subsequent studies.

Table 1. Novel 1,5-DS-T compounds synthetized by Cortes-Garcia et al.

\begin{tabular}{cccc}
\hline Entry & $\begin{array}{c}\text { Compound } \\
\text { code }\end{array}$ & $\mathbf{R} \mathbf{1}$ & $\mathbf{R 2}$ \\
\hline 1 & $1 \mathrm{a}$ & $\mathrm{H}$ & $C y$ \\
2 & $1 \mathrm{~b}$ & $\mathrm{H}$ & $t-B u$ \\
3 & $2 \mathrm{a}$ & $4-\mathrm{F}$ & $C y$ \\
4 & $2 \mathrm{~b}$ & $4-\mathrm{F}$ & $t-B u$ \\
5 & $3 \mathrm{a}$ & $2-\mathrm{F}$ & $C y$ \\
6 & $3 \mathrm{~b}$ & $2-\mathrm{F}$ & $t-B u$ \\
7 & $4 \mathrm{a}$ & $2,3-\mathrm{di}-\mathrm{F}$ & $C y$ \\
8 & $4 \mathrm{~b}$ & $2,3-\mathrm{di}-\mathrm{F}$ & $t-B u$ \\
9 & $5 \mathrm{a}$ & $2,4-\mathrm{di}-\mathrm{F}$ & $C y$ \\
10 & $5 \mathrm{~b}$ & $2,4-\mathrm{di}-\mathrm{F}$ & $t-B u$ \\
11 & $6 \mathrm{a}$ & $2,5-\mathrm{di}-\mathrm{F}$ & $C y$ \\
12 & $6 \mathrm{~b}$ & $2,5-\mathrm{di}-\mathrm{F}$ & $t-B u$ \\
13 & $7 \mathrm{a}$ & $3,4-\mathrm{di}-\mathrm{F}$ & $C y$ \\
14 & $7 \mathrm{~b}$ & $3,4-\mathrm{di}-\mathrm{F}$ & $t-B u$ \\
15 & $8 \mathrm{a}$ & $2,3,4,5,6-$ Penta-F & $C y$ \\
16 & $8 \mathrm{~b}$ & $2,3,4,5,6-$ Penta-F & $t-B u$
\end{tabular}




\begin{tabular}{|c|c|c|c|}
\hline 17 & $9 a$ & $2-\mathrm{Cl}$ & $C y$ \\
\hline 18 & $9 \mathrm{c}$ & $2-\mathrm{Cl}$ & $t-B u$ \\
\hline 19 & $10 a$ & $4-\mathrm{Cl}$ & $C y$ \\
\hline 20 & $10 \mathrm{~b}$ & $4-\mathrm{Cl}$ & $t-B u$ \\
\hline 21 & $11 \mathrm{a}$ & $2-\mathrm{Br}$ & $C y$ \\
\hline 22 & $11 b$ & $2-\mathrm{Br}$ & $t-B u$ \\
\hline 23 & $12 a$ & $4-\mathrm{Br}$ & $C y$ \\
\hline 24 & $12 b$ & $4-\mathrm{Br}$ & $t-B u$ \\
\hline 25 & $13 a$ & 4-OMe & $C y$ \\
\hline 26 & $13 b$ & 4-OMe & $t-B u$ \\
\hline 27 & $14 a$ & 3,4-di-OMe & $C y$ \\
\hline 28 & $14 \mathrm{~b}$ & 3,4-di-OMe & $t-B u$ \\
\hline 29 & $15 a$ & 2,3,4-tri-OMe & $C y$ \\
\hline 30 & $15 b$ & 2,3,4-tri-OMe & $t-B u$ \\
\hline 31 & $16 a$ & 2,4,5-tri-OMe & $C y$ \\
\hline 32 & $16 \mathrm{~b}$ & 2,4,5-tri-OMe & $t-B u$ \\
\hline 33 & $17 \mathrm{a}$ & 3,4,5-tri-OMe & $C y$ \\
\hline 34 & $17 \mathrm{~b}$ & 3,4,5-tri-OMe & $t-B u$ \\
\hline 35 & $18 \mathrm{a}$ & 2,4,5-tri-Me & $C y$ \\
\hline 36 & $18 \mathrm{~b}$ & 2,4,5-tri-Me & $t-B u$ \\
\hline 37 & $19 a$ & 4-(pyridin-2-yl) & $C y$ \\
\hline 38 & $19 b$ & 4-(pyridin-2-yl) & $\mathrm{t}-\mathrm{Bu}$ \\
\hline
\end{tabular}

The active and inactive structures from the DUD database were minimized by carrying out molecular mechanics using the UFF force field [16] in the Gaussian 3.9 software package [17] and the outputs were converted into .pdb files to prepare the ligands for the molecular docking studies.

\subsection{Docking ligand preparation}

Using Autodock Tools [18], one ligand was prepared to adding polar hydrogens and Gasteiger charges, rotatable (i.e., single) bonds were assigned by default, and a. pdbqt file was generated. This file was used as a template for the preparation of the rest of the ligands using the tool Raccon [19] that allows many structures to be prepared in .pdbqt file at the same time.

\subsection{Docking receptor preparation}

Two X-ray structures for the ABL kinase were downloaded in .pdb format from the PDB database [20]: PDB i.d. 2HZI, which contains the ligand JIN [21], and PDB i.d. 4TWP, which contains the ligand AXI [21]. The first one showed good interactions in the active site of ABL kinase and the second one for the T315I ABL kinase. After the preparation of the ligands in Autodock Tools, these X-ray structures were analyzed using Swiss PDB viewer [22] in order to find and correct any errors and to model any missing atoms, and after their minimized states were calculated using the AMBER force field in GROMACS adding polar hydrogens throughout the structures. Then, Kollman charges were added using Autodock Tools, and .pdbqt formats were generated for the docking calculations.

\subsection{Docking experiments}

Autodock 4 was used for rigid docking calculations using the Lamarckian genetic algorithm [23]. Tetrazole ligands were set in a $126 \AA$ x $126 \AA$ x $126 \AA$ grid box. A value of 0.37 was used for spacing calculations for the active and inactive ligands from the DUD database and these ligands were centered in each receptor. AD4.dat parameters were applied to all the ligands. Thus two different templates were generated, and formatted into .gpf and .dlg files, and then all of the ligands prepared for docking were obtained using the Raccon tool from Autodock Tools. The 
conditions for the docking calculations were in general 100 runs, a population size of 150, a total of 1000000 generations, a default value of 0.8 for the crossover rate, a mutant rate of 0.2 , and 100 individuals in each run [24].

\subsection{Docking performance assessment}

Scoring functions are commonly used to assess docking performance. In our study, decoys for ABL kinase, i.e., the compounds in the DUD database that are not active towards the kinase, were used to assess the docking performance of the active compounds, and then specificity and sensitivity values were obtained. The $\mathrm{pKi}$ values predicted from the negative and positive docking results were used as markers to distinguish active from inactive compounds [25]. Also, the original ligands from each receptor (JIN and AXI) were docked with the same conditions used for all other ligands in order to assess the performance of the docking using the RMSD value between the original coordinates and the predicted ones resulting from our docking protocol.

\subsection{Docking results analysis}

All of the results for each ligand were analyzed in Autodock Tools. The best free energies and $K i$ values were kept and afterwards the Ki values were converted in $\mathrm{pKi}$ values using equation 1 . All of the information was processed in order to obtain the representative graphics comparing the free energy and $\mathrm{pKi}$ values.

The analysis of hydrogen bonds was carried out for the complexed ligands and the docked ones, each with their respective receptor, using HBAT software [26], in order to determine the principal and important interactions. PyMol software was used to visualize the interactions.

\section{Results and discussion}

\subsection{Evaluation of the scoring function and search algorithm used in Autodock4.}

For all of the 584 total of compounds tested in docking studies, predicted free energy and Ki values were obtained and compiled for statistical analysis. Each ligand was analyzed using the graphical interface of Autodock Tools to determine the pose and whether the ligand was bound in the active site. Two plots (for active compounds and decoys) were made to reveal the general behavior of the pKi and free energy (Figures 4 and 5).

$$
p K i=-\log \left(\frac{K i}{1 \times 106}\right) \quad \text { Equation } 1
$$

\subsection{Statistical results}

The statistical results were obtained using the Bayesian theorem [27] with equations $2 a, 2 b, 2 c$, and the results are presented in table 2 . 
Table 2. Statistical results obtained using the Bayesian theorem

\begin{tabular}{c|c|c|c|c}
\hline \multicolumn{3}{c}{$\mathrm{N}=584$} \\
\hline Arue positives & False negatives & True negatives & False positives & Cutoff \\
\hline 85 & 14 & 123 & 262 & $10 \%(58)$ \\
\hline \multicolumn{2}{c|}{ Sensitivity (Se) } & 0.85 \\
\hline \multicolumn{2}{c}{ Specificity (Sp) } & 0.31 \\
\hline \multicolumn{2}{c}{ Enrichment Factor (EF) } & 10.79 \\
\hline Positive Predicted Value (PPV) & 0.24 \\
\hline Negative Predicted Value (NPV) & 1.12 \\
\hline & (LR) & 1.26 \\
\hline
\end{tabular}

The positive predicted and negative predicted values are the probabilities of finding as positive or negative one event [28]. In this case, the results of the evaluation of the conditions in the docking protocol helped us determine how the genetic algorithm worked with the chemical environment of the receptor and the chemical structures of active and inactive ABL kinase compounds.

\section{Bayesian equations}

$$
\begin{gathered}
S e=\frac{T P}{T P+F N} \quad \text { equation } 2 a \\
S p=\frac{T N}{T N+F P} \quad \text { equation } 2 b \\
P P V=\frac{T P}{T P+F P} \text { equation } 2 c \\
\left.N P V=\frac{T N}{T N}+F N\right) \quad \text { equation } 2 d
\end{gathered}
$$

Where: $\mathrm{Se}=$ Sensitivity; $\mathrm{Sp}=$ Specificity; $\mathrm{TP}=$ True positives; $\mathrm{FN}=$ False negatives; $\mathrm{PPV}=$ Positive predicted value; NPV= Negative predicted value 


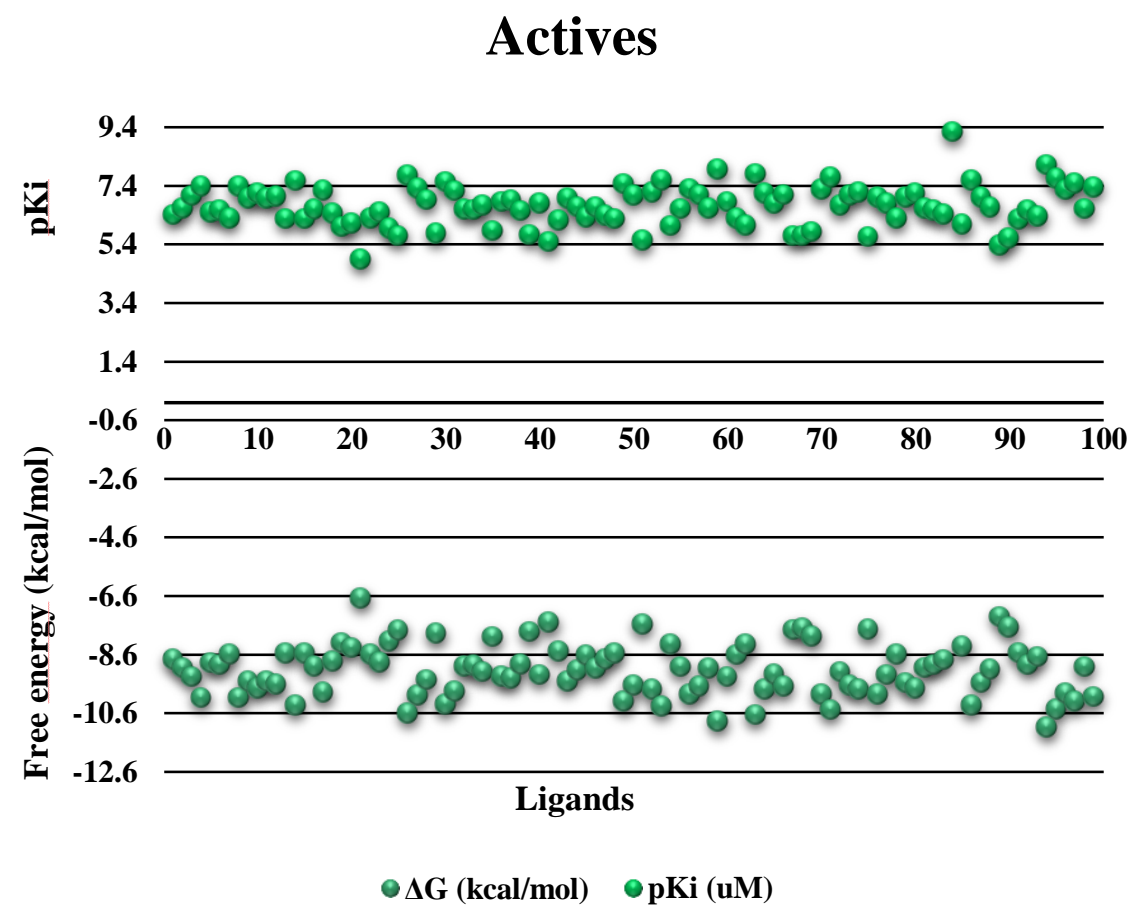

Figure 4. pKi and free energy values of the active set of ligands from the DUD database for the 2HZI receptor
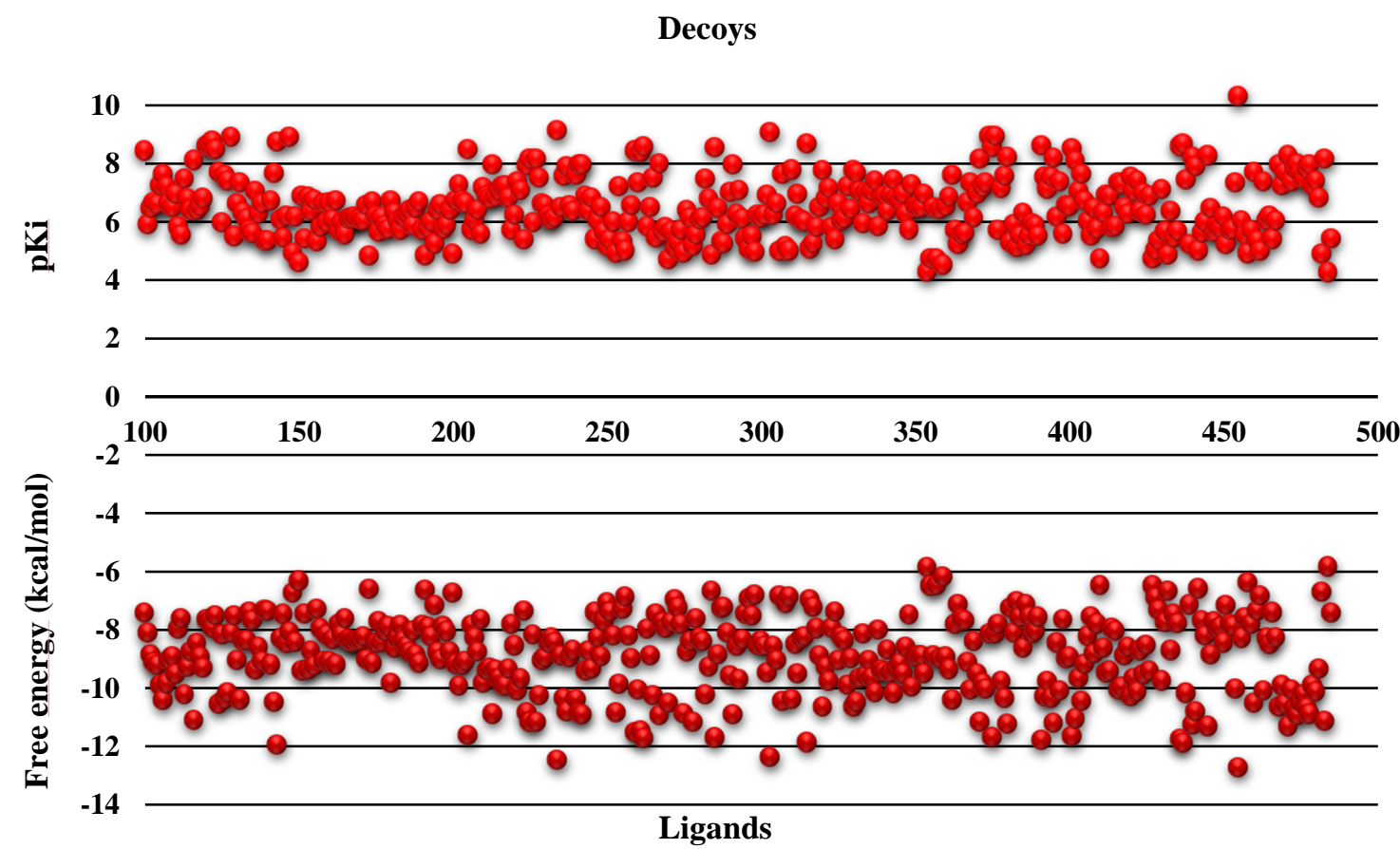

- $\Delta \mathrm{G}(\mathrm{kcal} / \mathrm{mol})$

Figure $5 \mathrm{pKi}$ and free energy values of the decoy (inactive) set of ligands from the DUD database for the 2HZI receptor

These results seem to be counterintuitive since decoys turn out to be false positives (262 compounds). The values used as cutoff to calculate the Se, Sp and for the PPV and NPV were using the $\mathrm{pKi}$ values from $6.03-9.24(-8.2$ to $-12.6 \mathrm{kcal} / \mathrm{mol})$ as actives (positive compounds), and below 
pKi values from $6.02(-8.18 \mathrm{Kcal} / \mathrm{mol})$ as inactives (negative compounds) this based in the docking results of active compounds considered as active ones in de DUD data base. The results derived of the Bayesian calculations showed that there were more false positives than false negatives: $\mathrm{Se}=0.85$ and $\mathrm{Sp}=0.31$. It means that the protocol of the docking study could better predict positive ligands as the active compounds than it could predict the negative ligands as the inactive ones. Nevertheless, the PPV and the NPV showed us how the protocol has the possibility of detecting well the negative or inactive ligands; thus, the conditions of the docking experiment were considered for the docking validation calculations using the structural information for the 2HZI and 4TWP complexes as well the same conditions with the 38 novel 1,5-DS-T compounds.

\subsection{Docking validation}

The X-ray structures were prepared as is described in the general procedure for docking calculations, treating the ligands and receptors separately. The ligand in the 2HZI structure was identified as JIN and that in the 4TWP structure as AXI. After the calculations, the .dlg files were visualized using Autodock tools and the best free energy, affinity constant, and pose coordinate results were kept. Figure 6 shows a comparison of the original conformations of the ligands and those obtained from our calculations. The RMSDs were calculated using PyMol between the heavy atoms in the native and docked structures and were found to be $1.754 \AA$ and $1.827 \AA$ for the 2HZI_JIN and 4TWP_AXI complexes, respectively, were below $2.00 \AA$ is the upper limit for validation of docking poses.

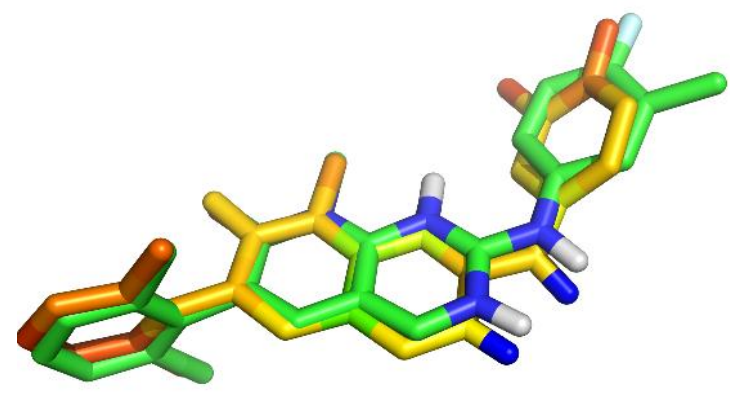

a) $\mathrm{RMSD}=1.827$

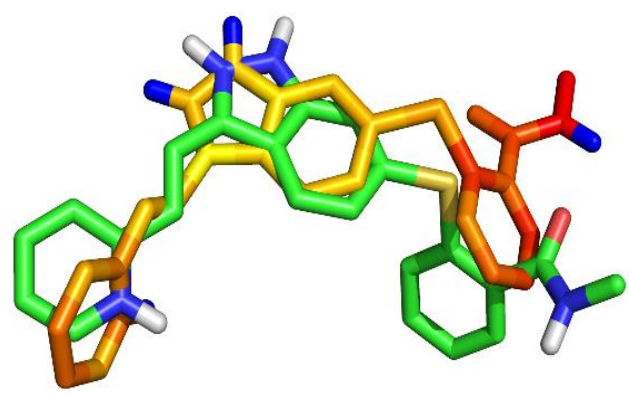

b) $\mathrm{RMSD}=1.754$

Figure 6 Superposition of complexed ligands and the predicted docking poses a: AXI from 4TWP, b: JIN from 2HZI

\subsection{Evaluation of the novel 1,5-DS-T compounds with the docking protocol conditions.}

The RMSD values resulting from the docking validation studies indicated that the conditions of the search method and the placement of coordinates in the grid box are appropriate for the 1,5-DS-T docking calculations. The 1,5-DS-T compounds were then prepared as were all of the ligands, and docking results of each compound were analyzed manually, and again the free energy, Ki values and the coordinates of the best pose were kept. The results are shown in the table 3.

The obtained results showed 3a, 9a, 11a and $11 \mathrm{~b}$ to be the best ligands for the 2HZI receptor and $1 \mathrm{a}, 5 \mathrm{a}, 10 \mathrm{a}$ and $13 \mathrm{a}$ to be the best for the 4TWP receptor. The binding energies and the Ki values of the best ligands for the 2HZI receptor are very different from those for the 4TWP receptor. At the same time, it is important to remember that the 4TWP receptor is a mutated ABL kinase and these ligands, according to the docking results, could be tested in vitro to experimentally determine their activities against this protein. 
Almost all the ligands interact with Lys 219 of the 2HZI protein and Met 316 of the 4TWP protein. To obtain all of the hydrogen bond interactions between the protein and the ligands, HBAT software was used to calculate the chemical properties of these bonds, and the results are shown in table 3. Lys 271 is the most common residue of the 2HZI receptor to which the ligands bind, while Met 316 is the most common residue of the 4TWP receptor to which the ligands bind. These interactions are shown in Figures 8 and 9. The results of the analysis of HBAT program using as starting structures the coordinates with the best-docked ligands are presented in table 4 . Interestingly, the bests predicted affinities came from ligands that contain halogens, were those interactions involving halogens are well known in biological structures [29 - 33], suggesting that those interactions (except for fluorine which is not a halogen-bond donor) could correspond to the sigma hole halogen bonding. Unfortunate the scoring function used in our methodology, is not capable to predict accurately this kind of interactions. At the same time, comparing the structures of pairs of ligands as well as comparing their binding and Ki values revealed big differences between the results when the R2 moiety is cyclohexane and when it is a less hydrophobic group. Specifically comparing the ligands that have best interaction modes with their respective receptors led us to conclude that a more hydrophobic R2 moiety displays higher binding energies.

Table 3. Docking results of the 1,5-DS-T compounds with 2HZI and 4TP receptors.

\begin{tabular}{|c|c|c|c|c|c|c|c|}
\hline \multirow[t]{2}{*}{ Entry } & \multirow[t]{2}{*}{ Ligand } & $\Delta \mathrm{G}(\mathrm{kcal} / \mathrm{mol})$ & $K i(\mathrm{nM})$ & $p K i(\mathrm{nM})$ & $\begin{array}{c}\Delta \mathrm{G} \\
(\mathrm{kcal} / \mathrm{mol})\end{array}$ & $K i(\mathrm{nM})$ & $p K i(\mathrm{nM})$ \\
\hline & & \multicolumn{3}{|c|}{$2 \mathrm{HZI}$} & \multicolumn{3}{|c|}{ 4TWP } \\
\hline 1 & $1 \mathrm{a}$ & -11.93 & 1.79 & 8.75 & -12.89 & 1.79 & 9.45 \\
\hline 2 & $1 b$ & -11.28 & 5.4 & 8.27 & -11.77 & 2.36 & 8.63 \\
\hline 3 & $2 a$ & -11.64 & 2.95 & 8.53 & -13.04 & 2.95 & 9.56 \\
\hline 4 & $2 b$ & -10.98 & 8.88 & 8.05 & -11.34 & 4.87 & 8.31 \\
\hline 5 & $3 a$ & -12.6 & 1.04 & 8.98 & -12.58 & 1.04 & 9.22 \\
\hline 6 & $3 b$ & -11.36 & 0.101 & 8.33 & -11.74 & 2.47 & 8.61 \\
\hline 7 & $4 a$ & -11.31 & 5.14 & 8.29 & -12.23 & 1.09 & 8.96 \\
\hline 8 & $4 b$ & -10.99 & 8.86 & 8.05 & -11.31 & 5.16 & 8.29 \\
\hline 9 & $5 a$ & -11.59 & 3.2 & 8.49 & -12.82 & 3.2 & 9.4 \\
\hline 10 & $5 b$ & -11 & 8.61 & 8.06 & -11.7 & 2.64 & 8.58 \\
\hline 11 & $6 a$ & -11.45 & 4.02 & 8.4 & -11.57 & 3.32 & 8.48 \\
\hline 12 & $6 b$ & -11.14 & 6.8 & 8.17 & -11.65 & 2.9 & 8.54 \\
\hline 13 & $7 a$ & -11.06 & 7.83 & 8.11 & -12.16 & 1.22 & 8.91 \\
\hline 14 & $7 b$ & -10.95 & 9.45 & 8.02 & -11.56 & 3.38 & 8.47 \\
\hline 15 & $8 a$ & -11.08 & 7.57 & 8.12 & -11.76 & 2.41 & 8.62 \\
\hline
\end{tabular}




\begin{tabular}{|c|c|c|c|c|c|c|c|}
\hline 16 & $8 b$ & -10.89 & 10.45 & 7.98 & -11.38 & 4.57 & 8.34 \\
\hline 17 & $9 a$ & -12.54 & 0.64 & 9.19 & -11.49 & 3.81 & 8.42 \\
\hline 18 & $9 b$ & -11.8 & 2.25 & 8.65 & -11.74 & 2.5 & 8.6 \\
\hline 19 & $10 a$ & -11.96 & 2.02 & 8.69 & -13.73 & 2.02 & 10.06 \\
\hline 20 & $10 \mathrm{~b}$ & -11.34 & 4.84 & 8.32 & -12.19 & 1.15 & 8.94 \\
\hline 21 & $11 a$ & -12.19 & 1.16 & 8.94 & -12.22 & 1.1 & 8.96 \\
\hline 22 & $11 b$ & -12.39 & 0.82 & 9.08 & -12.39 & 0.824 & 9.08 \\
\hline 23 & $12 a$ & -12.12 & 1.31 & 8.88 & -13.24 & 1.31 & 9.71 \\
\hline 24 & $12 b$ & -11.44 & 4.1 & 8.39 & -11.91 & 1.85 & 8.73 \\
\hline 25 & $13 a$ & -11.75 & 2.42 & 8.62 & -13.8 & 2.42 & 10.11 \\
\hline 26 & $13 b$ & -11.07 & 7.65 & 8.12 & -11.71 & 2.63 & 8.58 \\
\hline 27 & $14 a$ & -12.18 & 1.18 & 8.93 & -12.26 & 1.04 & 8.98 \\
\hline 28 & $14 b$ & -11.08 & 7.55 & 8.12 & -12.62 & 1.07 & 9.25 \\
\hline 29 & $15 a$ & -11 & 8.46 & 8.07 & -12.81 & 8.46 & 8.07 \\
\hline 30 & $15 b$ & -10.54 & 18.87 & 7.72 & -10.7 & 14.44 & 7.84 \\
\hline 31 & $16 a$ & -11.38 & 4.59 & 8.34 & -11.69 & 2.68 & 8.57 \\
\hline 32 & $16 b$ & -10.95 & 17.28 & 7.76 & -10.33 & 26.9 & 7.57 \\
\hline 33 & $17 \mathrm{a}$ & -11.19 & 6.26 & 8.2 & -11.69 & 2.72 & 8.57 \\
\hline 34 & $17 \mathrm{~b}$ & -10.78 & 12.52 & 7.9 & -11.78 & 2.31 & 8.64 \\
\hline 35 & $18 a$ & -12.03 & 1.51 & 8.82 & -11.51 & 3.68 & 8.43 \\
\hline 36 & $18 b$ & -11.5 & 3.7 & 8.43 & -12.24 & 1.07 & 8.97 \\
\hline 37 & $19 a$ & -12.34 & 0.89 & 9.05 & -13.7 & 0.89 & 10.05 \\
\hline 38 & $19 b$ & -11.91 & 1.85 & 8.73 & -12.67 & 1.85 & 9.28 \\
\hline
\end{tabular}




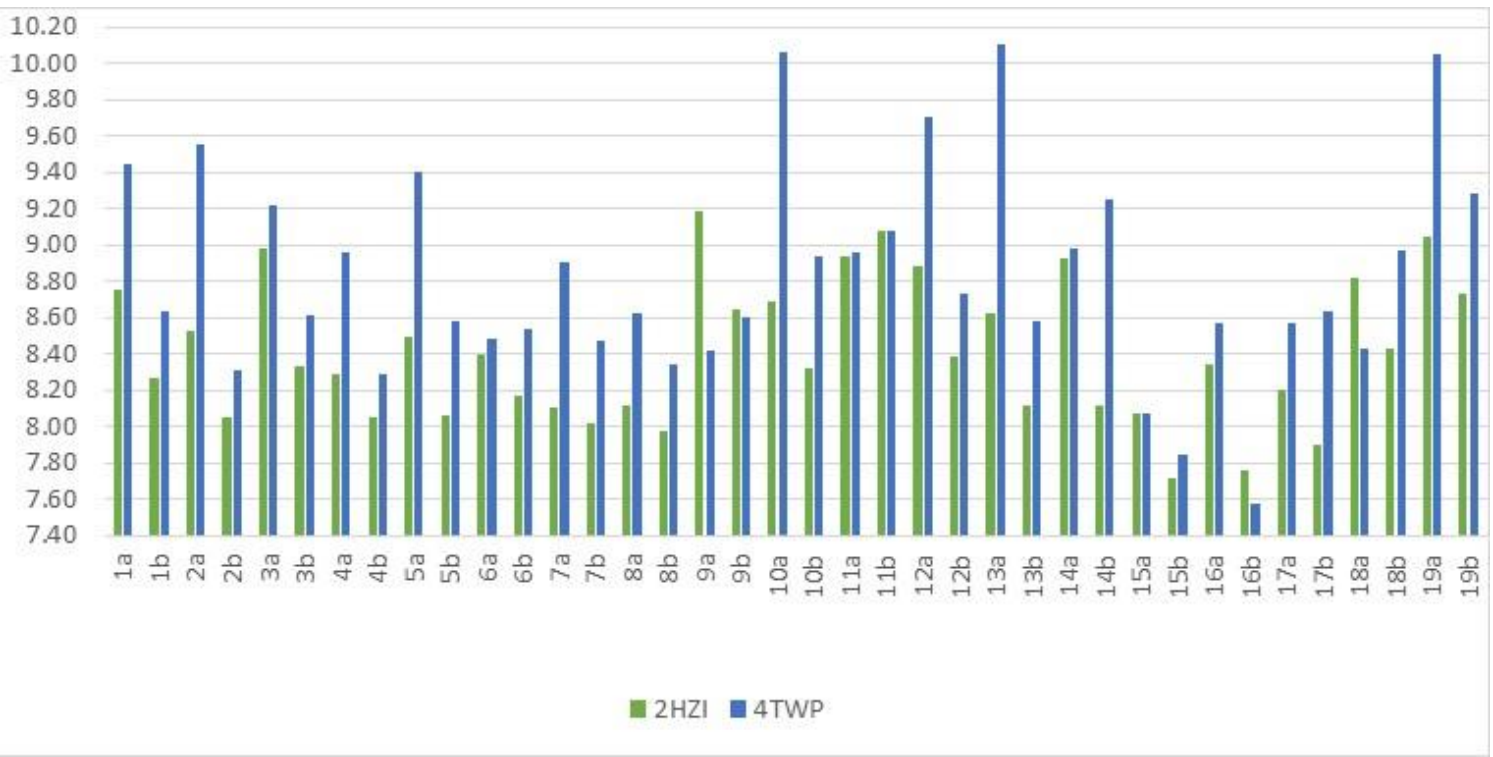

Figure $7 \mathrm{pKi}$ values of the 1,5-DS-T ligands for the 2HZI and 4TWP receptors obtained from the docking studies with Autodock4

Based on a visual analysis of the docking results for each of the 1,5-DS-T ligands, we selected those that interacted with the active site of the proteins. The docking predictions indicated the 1,5-DS-T ligands to have more affinity for the 4TWP receptor (i.e., the T315I mutant) than for the 2HZI receptor. Thus, the proposed ligands may be good inhibitors for the specific ABL kinase that is resistant to imatinib.

The ligands that showed the same set of predicted interactions for the 2HZI receptor are $3 a, 9 a$, 11a and 11b. For the 4WTP receptor, 1a, 5a, 10a and 13a displayed common interactions. The poses of the best ligands were analyzed to find the common interactions to establish the principal chemical moieties or features that contribute to the free energy and Ki results, and the results of this analysis are shown in the Figure 8. Analyzing the poses between the best 1,5-DS-T ligands for the 2HZI receptor revealed that it formed similar interactions with the halogens of three ligands, specifically with halogens attached to position 2 of the R1 substituent. The ligand with chlorine showed good predicted $\mathrm{Ki}$ and free energy, nevertheless the fluorine substituted with the best free energy and $\mathrm{Ki}$ values. As Cortes-García et al. noted in their publication of the synthesis of these novel 1,5-DS-T compounds, that including halogens in the synthesis was the highest priority in the effort to make compounds displaying a high specificity and affinity for the ABL kinase. Another interesting chemical feature was that the 1,5-DS-T ligands with the Cy substituent (R2) showed the best interactions, maybe because this moiety was interacting with a hydrophobic region in the binding site of the receptor. We chose the collection of ligands so that each one had a structural homologue as shown in Figures 8 and 9 to help relate the results to specific chemical features. At the same time, a feature that is very beneficial for our work is that the best ligands for 4TWP have almost the same pose in the binding site, as shown in Figure 9b. 
Table 4. HB interactions calculated using HBAT software.

\begin{tabular}{|c|c|c|c|c|c|c|}
\hline Receptor & Ligand & HB type & Donor & Acceptor & Dist. HA & Dist. XA \\
\hline \multirow{15}{*}{$2 \mathrm{HZI}$} & \multirow{3}{*}{$9 a$} & NH --- N & Gly249 & $112 \mathrm{~h}$ & 2.146 & 3.124 \\
\hline & & NH --- N & Lys271 & $112 \mathrm{~h}$ & 2.818 & 3.150 \\
\hline & & $\mathrm{NH}$--- O & $112 \mathrm{~h}$ & Met318 & 2.129 & 2.956 \\
\hline & \multirow{4}{*}{$11 b$} & NH --- N & Lys271 & $144 d d$ & 2.794 & 3.514 \\
\hline & & NH --- N & Lys271 & $144 d d$ & 2.302 & 3.020 \\
\hline & & $\mathrm{OH}---\mathrm{N}$ & Thr315 & $144 \mathrm{dd}$ & 2.526 & 3.050 \\
\hline & & NH --- O & $144 \mathrm{dd}$ & Thr315 & 2.195 & 3.050 \\
\hline & \multirow{4}{*}{$3 a$} & NH --- N & Gly249 & $96 \mathrm{bb}$ & 1.963 & 2.951 \\
\hline & & NH --- N & Lys271 & $96 \mathrm{bb}$ & 2.911 & 3.386 \\
\hline & & $\mathrm{NH}$--- N & Lys271 & $96 \mathrm{bb}$ & 2.657 & 2.946 \\
\hline & & $\mathrm{NH}$--- O & $96 \mathrm{bb}$ & Met318 & 2.106 & 2.847 \\
\hline & \multirow{4}{*}{$11 a$} & $\mathrm{NH}---\mathrm{N}$ & Gly249 & $143 \mathrm{cc}$ & 2.948 & 3.165 \\
\hline & & $\mathrm{NH}---\mathrm{N}$ & Asp 381 & $143 \mathrm{cc}$ & 2.048 & 2.984 \\
\hline & & NH --- N & Asp381 & $143 \mathrm{cc}$ & 1.997 & 2.829 \\
\hline & & NH --- N & Phe382 & $143 \mathrm{cc}$ & 2.991 & 3.452 \\
\hline \multirow{10}{*}{ 4TWP } & \multirow{4}{*}{$13 a$} & $\mathrm{NH}$--- N & Met316 & $126 \mathrm{p}$ & 1.948 & 2.904 \\
\hline & & $\mathrm{NH}$--- N & Met316 & $126 p$ & 2.380 & 3.113 \\
\hline & & NH --- O & Asp379 & $126 \mathrm{p}$ & 2.085 & 2.886 \\
\hline & & $\mathrm{NH}$--- O & Phe380 & $126 p$ & 2.959 & 3.824 \\
\hline & \multirow{2}{*}{$10 \mathrm{a}$} & NH --- N & Met316 & $100 a$ & 1.974 & 2.970 \\
\hline & & $\mathrm{NH}$--- N & Met316 & $100 \mathrm{a}$ & 2.260 & 3.054 \\
\hline & \multirow{2}{*}{$1 \mathrm{a}$} & NH --- N & Met316 & $106 \mathrm{~d}$ & 2.073 & 3.093 \\
\hline & & NH --- N & Met316 & $106 \mathrm{~d}$ & 2.118 & 2.997 \\
\hline & \multirow{2}{*}{$5 a$} & NH --- N & Met316 & $137 \mathrm{w}$ & 1.911 & 2.931 \\
\hline & & NH --- N & Met316 & $137 w$ & 2.081 & 2.959 \\
\hline
\end{tabular}



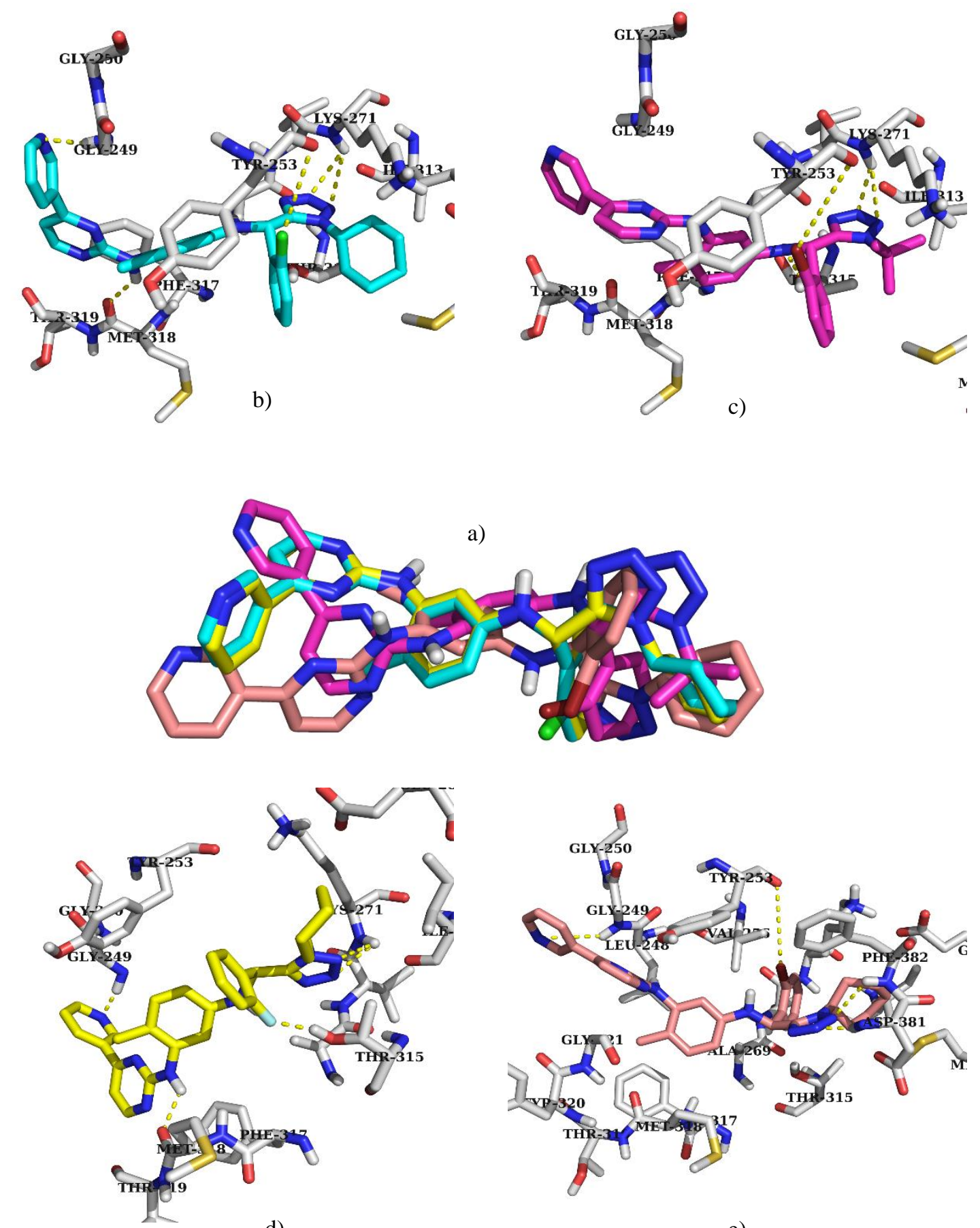

d)

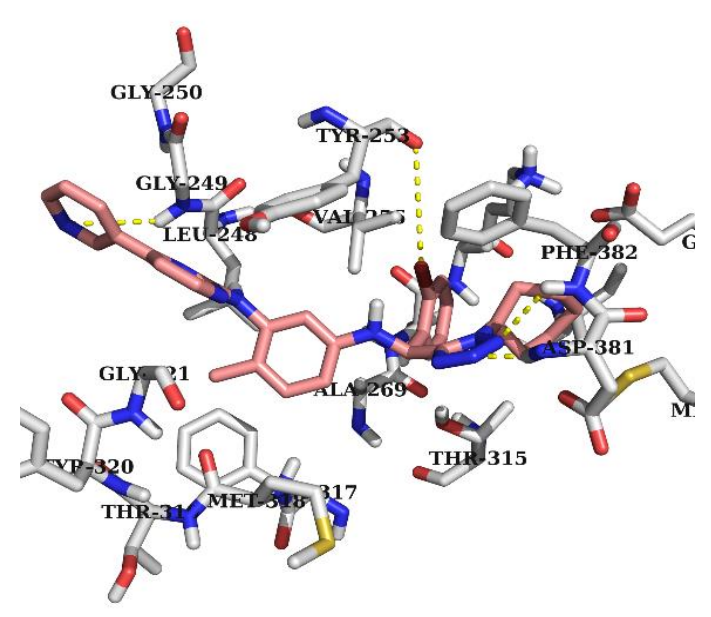

e)

Figure 8 Alignment of the best ligands predicted for the 2HZI receptor and their interactions in the binding site. a): Alignment of the ligands $3 a, 9 a, 11 a$ and $11 b$. Interactions of the binding site with b) $9 a$, c) 11b, d) 3a, and e) 11a. 


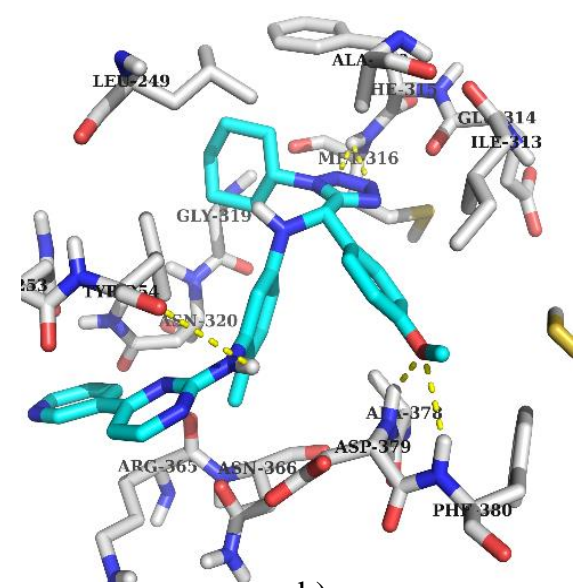

b)

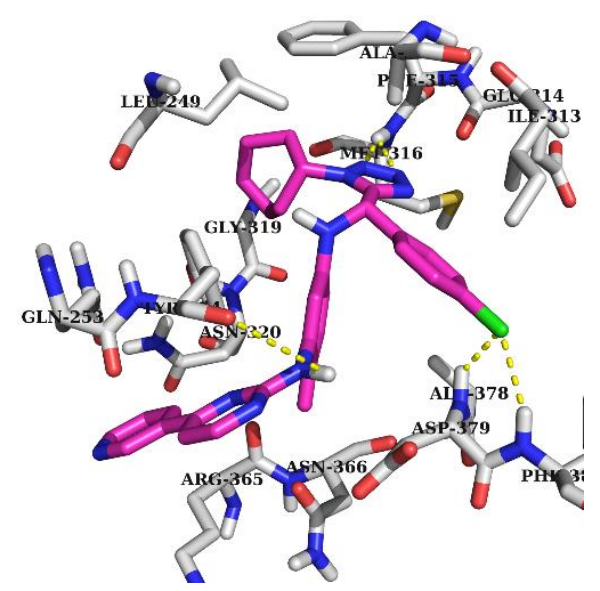

c)

a)

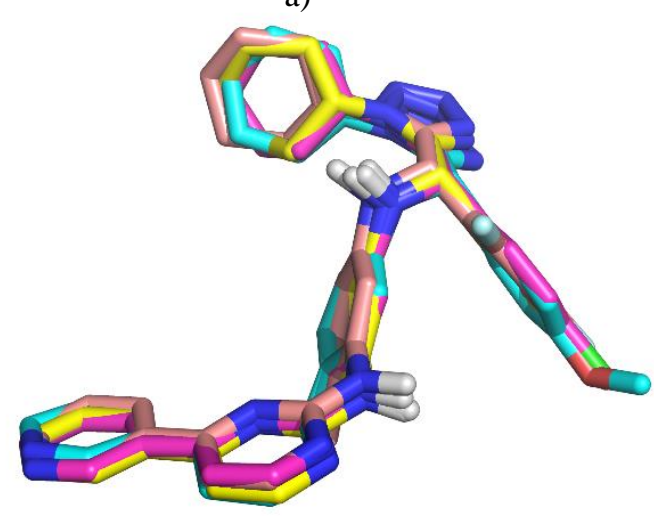

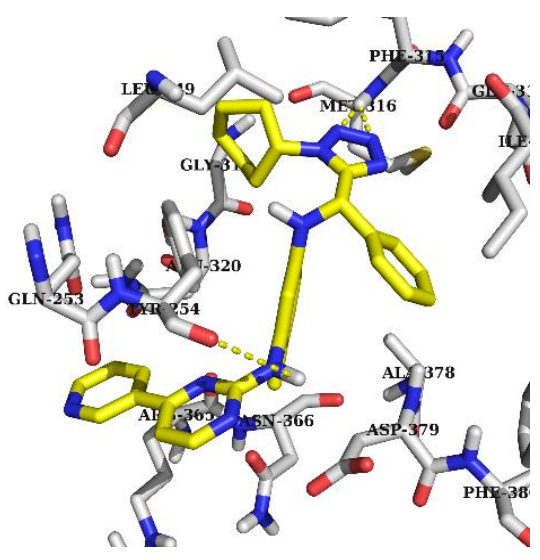

d)

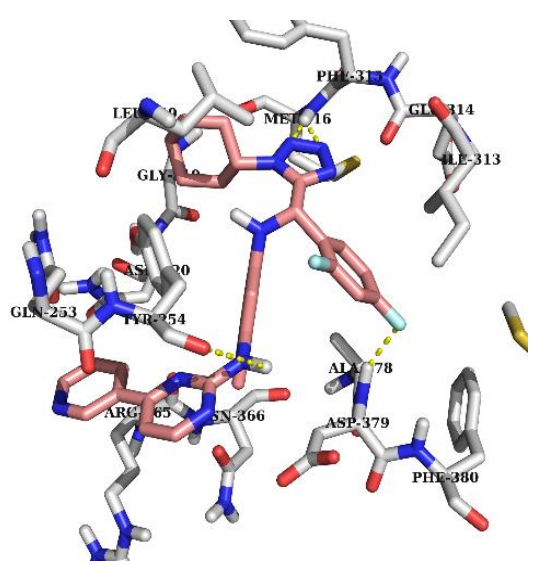

e)

Figure 9 Alignment of the best ligands predicted for the 4TWP receptor and their interactions in the binding site. a): Alignment of the ligands 1a, 5a, 10a and 13a. Interactions of the binding site with b): 13a, c): 10a, d): 1a, and e):5a. 
Table 5. Side-by-side comparison of the chemical structures of the best ligands predicted for the 4TWP receptor and the respective analogues of these ligands.

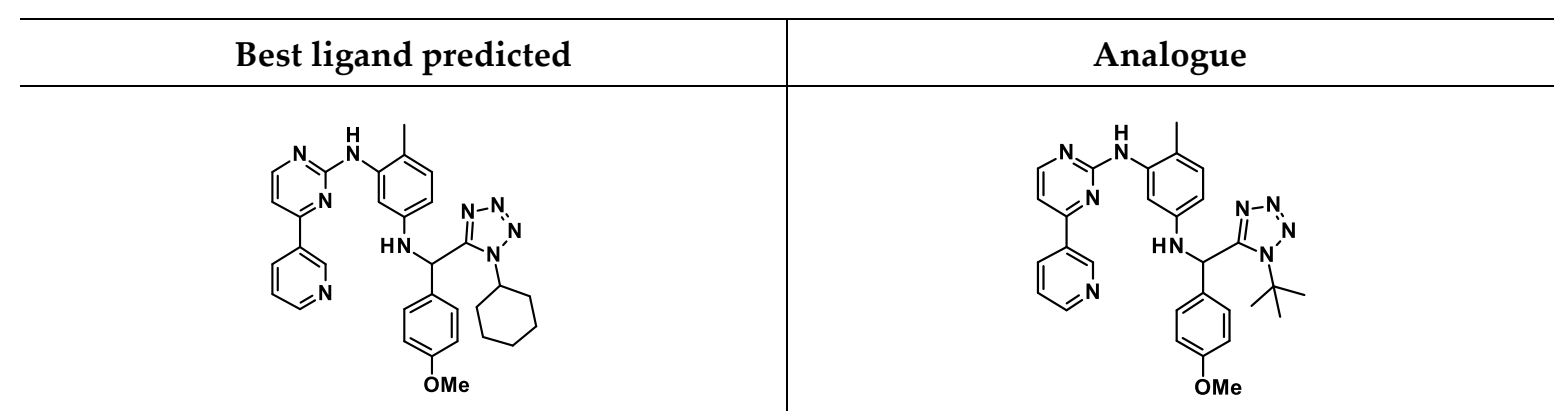

13a: $\Delta \mathrm{G}=-13.8 \mathrm{kcal} / \mathrm{mol} ; \mathrm{Ki}=0.07 \mu \mathrm{M}$<smiles>Cc1ccc(NC(c2ccc(Cl)cc2)c2nnnn2C2CCCCC2)cc1Nc1nccc(-c2cccnc2)n1</smiles>

10a: $\Delta \mathrm{G}=-13.73 \mathrm{kcal} / \mathrm{mol} ; \mathrm{Ki}=0.08 \mu \mathrm{M}$<smiles>Cc1ccc(NC(c2ccccc2)c2nnnn2C2CCCCC2)cc1Nc1nccc(-c2cccnc2)n1</smiles>

1a: $\Delta \mathrm{G}=-12.89 \mathrm{kcal} / \mathrm{mol} ; \mathrm{Ki}=0.35 \mu \mathrm{M}$<smiles>Cc1ccc(NC(c2ccc(F)cc2F)c2nnnn2C2CCCCC2)cc1Nc1nccc(-c2cccnc2)n1</smiles>

5a: $\Delta \mathrm{G}=-12.82 \mathrm{kcal} / \mathrm{mol} ; \mathrm{Ki}=0.39 \mu \mathrm{M}$ 13b: $\Delta \mathrm{G}=-11.71 \mathrm{kcal} / \mathrm{mol} ; \mathrm{Ki}=2.63 \mu \mathrm{M}$<smiles>Cc1ccc(NC(c2ccc(Cl)cc2)c2nnnn2C(C)(C)C)cc1Nc1nccc(-c2cccnc2)n1</smiles>

10b: $\Delta \mathrm{G}=-12.19 \mathrm{kcal} / \mathrm{mol} ; \mathrm{Ki}=1.15 \mu \mathrm{M}$

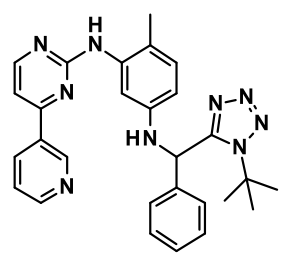

1b: $\Delta \mathrm{G}=-11.77 \mathrm{kcal} / \mathrm{mol} ; \mathrm{Ki}=2.36 \mu \mathrm{M}$

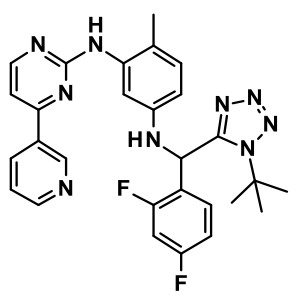

5b: $\Delta \mathrm{G}=-11.7 \mathrm{kcal} / \mathrm{mol} ; \mathrm{Ki}=2.64 \mu \mathrm{M}$ 
Table 6. Side-by-side comparison of the chemical structures of the best ligands predicted for the 2HZI receptor and the respective analogues of these ligands.

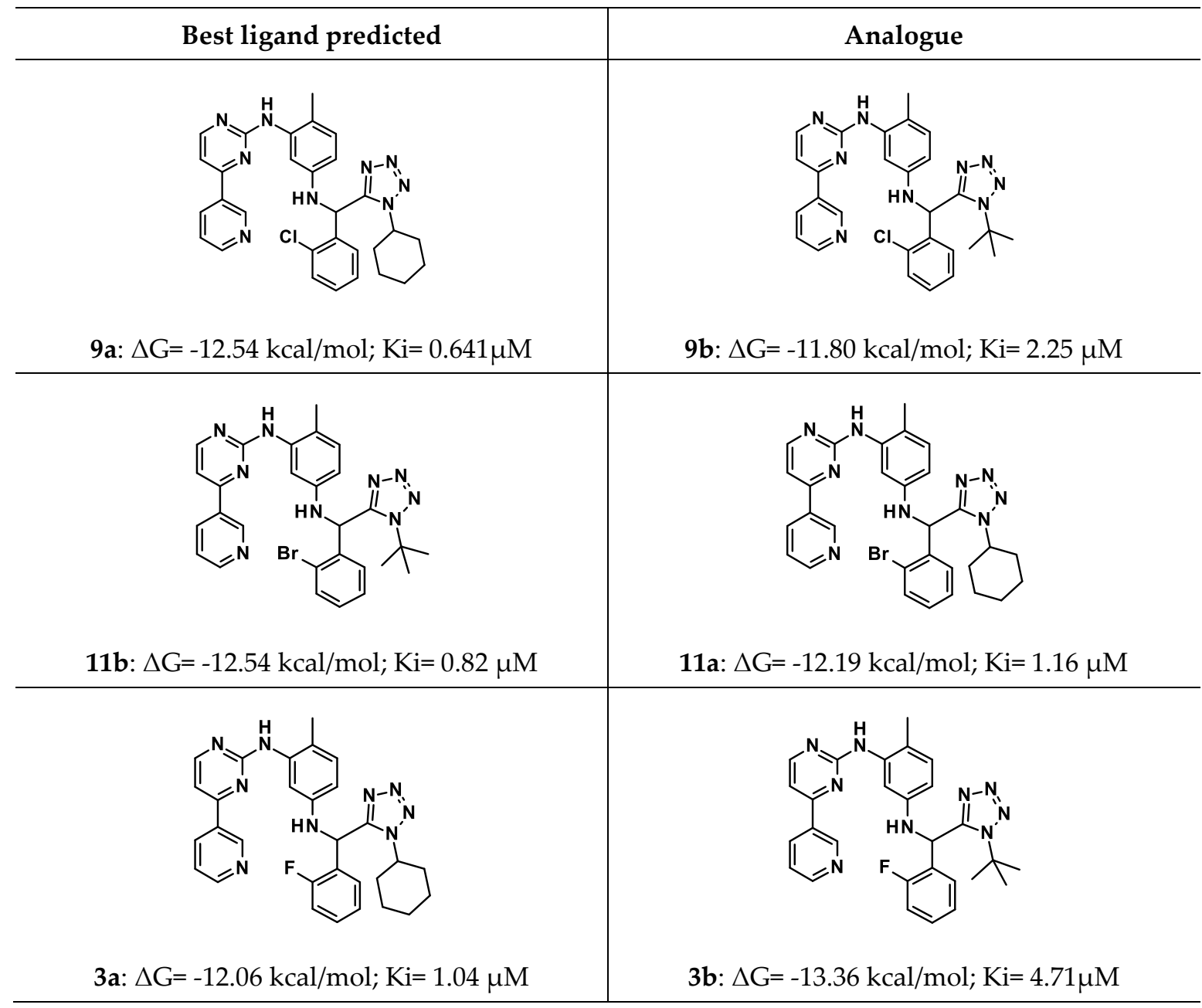

Analyzing the interactions of the best 1,5-DS-T ligands for each receptor to be between the halogens attached to position 2 of the R1 in the 2HZI receptor and revealed the most common and important interactions for the 1,5-DS-T ligands with the 4TWP receptor.

From the results resumed in table 6, it is seen that the Ki values could be improved by a modification in the hydrophobic tetrazole region. In this way, docking experiments were carried out with hypothetical structures modified in this region, using the same protocol that was used for the 38 1,5-DS-T and as a receptor PDB code 2HZI. The chemical structures and their docking results are presented at the table 7 . It is noteworthy that results of the ligand 9a-6 that containing the adamantly moiety, resulted with a free energy of -12.48 and a $\mathrm{Ki}$ of $0.705 \mathrm{nM}(0.000705 \mu \mathrm{M})$ which has the lower Ki values. 
Table 7. Docking results derived from 9a 1,5-DS-T ligand, where we have proposed a chemical modification in R2 (figure 3.) that improves the predicted affinity toward 2HZI crystallographic structure. Note that the Ki values obtained are predicted in a nM concentration.

\begin{tabular}{|c|c|c|}
\hline Chemical structure & Predicted $\Delta \mathrm{G}(\mathrm{kcal} / \mathrm{mol})$ & $K i(\mathrm{nM})$ \\
\hline $9 a-1$ & -11.94 & 1.78 \\
\hline 9a-2 & -11.41 & 4.30 \\
\hline $9 a-3$ & -11.60 & 3.12 \\
\hline $9 a-4$ & -12.35 & 0.87 \\
\hline & -11.20 & 6.2 \\
\hline $9 a-5$ & & \\
\hline
\end{tabular}


Table 7. Docking results derived from 112h 1,5-DS-T ligand, where we have proposed a chemical modification in R2 (figure 3.) that improves the predicted affinity toward 2HZI crystallographic structure. Note that the Ki values obtained are predicted in a $\mathrm{nM}$ concentration. (Continuation)...

\begin{tabular}{|l|l|l|}
\hline & Predicted $\Delta \mathrm{G}(\mathrm{kcal} / \mathrm{mol})$ & $K i(\mathrm{nM})$ \\
\hline
\end{tabular}

\section{Conclusions}

The halogen interaction is important for the binding mode of these 1,5-DS-T ligands [34]. Two possible interactions would arise from hydrogen bonding or sigma hold interactions. To demonstrate this, an appropriate scoring function as Autodock VinaXB [35], or QM/MM combined with GMBSA [36], could be used.

\section{Conflict of interest}

The authors declare no conflict of interest.

\section{Acknowledgments}

We thank to CONACyT for the fellowship 305150, and to the Universidad Michoacana support from CIC-UMSNH (2.18).

\section{References}

1. Ben-Neriah, Y.; Q. Daley, G.; Mes-Masson, A. M.; N. Witte, O.; Baltimore, D. The chronic myelogenous leukemia-specific P210 protein is the product of the bcr/abl hybrid gene. Science, 1986, 233, 212-214, DOI: 10.1126/science.3460176

2. Von Bubnoff, N.; Duyster, J. Chronic myelogenous leukemia: treatment and monitoring. Dtsch Arztebl Int, 2010, 107, 114-21, DOI: 10.3238/arztebl.2010.0114

3. Colicelli, J. ABL Tyrosine Kinases: Evolution of Function, Regulation, and Specificity. Science Signaling, 2011, 3, 139, DOI: 10.1126/scisignal.3139re6.

4. T. Abelson, H.; S. Rabstein, L. Lymphosarcoma: Virus-induced Thymic-independent Disease in Mice. Cancer Research, 1970, 30, 2213-2222, DOI: Published August 1970. 
5. Kumar, H.; Raj, U; Gupta, S.; Tripathi, R.; Kumar Varadwaj, P. Systemic Review on Chronic Myeloid Leukemia: Therapeutic Targets, Pathways and Inhibitors. J Nucl Med Radiat Ther, 2015, 6, 1-7, DOI: 10.4172/2155-9619.1000257

6. Baccarani, M.; Deininger, M.W.; Rosti,G.; Hochhaus, A.; Soverini, S.; Apperley, J.F.; Cervantes, F.; Clark, R. E.; Cortes, J. E.; Guilhot, F.; Hjorth-Hansen, H.; Hughes, T. P.; Kantarjian, H. M.; Kim, D. W.; Larson, R. A.; Lipton, J. H.; Mahon, F. X.; Martinelli, G.; Mayer, J.; Muller, M. C.; Niederwieser, D.; Pane, F.; Radich, J. P.; Rousselot, P.; Saglio, G.; Sabele, S.; Schiffer, C.; Silver, R.; Simonsson, B.; Steegmann,J. L.; Goldman, J. M.; Hehlmann, R. European LeukemiaNet recommendations for the management of chronic myeloid leukemia: 2013. Blood, 2013, 122, 872-884, DOI: 10.1182/blood-2013-05-501569.

7. Kantarjian, H.; Sawyers, C.; Hochhaus, A.; Guilhot, F.; Schiffer, C.; Gambacorti-Passerini, C.; Neiderwieser, D.; Resta, D.; Capdeville, R.; Zoellner, U.; Talpaz M.; Druker. B. Hematologic and cytogenetic responses to imatinib mesylate in chronic myelogenous leukemia. N Engl J Med 2002, 346, 9 , 645-652, DOI: 10.1056/NEJMoa011573.

8. Capdeville, R.; Buchdunger, E.; Zimmermann, J.; Matter, A. Glivec (STI571, imatinib), a rationally developed, targeted anticancer drug. Nat Rev Drug Discov 2002, 1, 403-502, DOI: 10.1038/nrd839.

9. Desogus, A.; Schenone, S.; Brullo, C.; Tintori, C.; Musumeci, F. Bcr-Abl tyrosine kinase inhibitors: a patent review. Expert Opinion Ther. Patents, 2015, 25, 1-16, DOI: 10.1517/13543776.2015.1012155.

10. O'Hare, T.; Shakespeare, W. C.; Zhu, X.; Eide, C. A.; Rivera, V. M.; Wang, F.; Adrian, L. T.; Zhou, T.; Huang, W-S.; Xu, O.; Metcalf, C. A.; Tyner, J. W.; Loriaux, M. M.; Corbin, A. M.; Wardwell, S.; Ning, Y.; Keats, J. A.; Wang, Y.; Sundaramoorthi, R.; Thomas, M.; Zhou, D.; Snodgrass, J.; Commodore, L.; Sawyer, T. K.; Dalgarno, D. C.; Deininger, M. W. N.; Druker, B. J.; Clackson, T. AP24534, a pan-BCR-ABL inhibitor for chronic myeloid leukemia, potently inhibits the T315I mutant and overcomes mutation-based resistance. Cancer Cell, 2009, 16, 5, 401-412, DOI: 10.1016/j.ccr.2009.09.028.

11. Zhou, T.; Parillon, L.; Li, F.; Wang, Y.; Keats, J.; Lamore, S.; Xu, O.; Shakespeare, W.; Dalgarno, D.; Zhu, X. Crystal structure of the T315I mutant of Abl kinase. Chem Biol Drug Des, 2007, 70, 171-181, DOI: 10.1111/j.1747-0285.2007.00556.x.

12. Pemovska, T.; Johnson, E.; Kontro, M.; Repasky, G. A.; Chen, J.; Wells, P.; Cronin, C. N.; McTigue, M.; Kallioniemi, O.; Porkka, K.; Murray, B. W.; Wennerberg, K. Axitinib effectively inhibits BCR-ABL1 (T315I) with a distinct binding conformation. Nature, 2015, 5, 102-105, DOI: 10.1038/nature14119.

13. Cortes-García, C. J.; Jácome A.; Rentería A.; Gámez, R. Synthesis of 1,5-disubstituted tetrazoles containing a fragment of the anticancer drug imatinib via a microwave-assisted Ugi-azide reaction. Monat Fur Chem, 2016, 147, 1277-1290, DOI: https://doi.org/10.1007/s0070.

14. Huang, N.; Schoichet, B. K.; Irwing, J. J. Benchmarking Sets for Molecular Docking. J Med Chem, 2006, 49, 6789-6801, DOI: 10.1021/jm0608356.

15. Swain, M. chemicalize.org. J Chem Inf Model, 2012, 52, 613-615, DOI: 10.1021/ci300046g.

16. Casewit, C. J.; Colwell, K. S.; Rappé, A. K. Application of a Universal Force Field to Organic Molecules. J Am Chem Soc. 1992,114, 10035-10046, DOI: 10.1021/ja00051a041.

17. Gaussian 09, Revision E.01, Frisch M. J.; Trucks, G. W.; Schlegel, H. B.; Scuseria, G. E.; Robb, M. A.; Cheeseman, J. R.; Scalmani, G.; Barone, V.; Mennucci, B.; Petersson, G. A.; Nakatsuji, H.; Caricato, M.; Li, X.; Hratchian, H. P.; Izmaylov, A. F.; Bloino, J.; Zheng, G.; J. L.; Hada, M.; Ehara, Toyota, M. K.; R.; Fukuda, J.; Hasegawa, M.; Ishida, T.; Nakajima, Y.; Honda, O.; Kitao, H.; Nakai, T.; Vreven, J. A.; Montgomery, Jr., J. E.; Peralta, F.; Ogliaro, M.; Bearpark, J. J.; Heyd, E.; Brothers, K. N.; Kudin, V. N.; Staroverov, R.; Kobayashi, J.; Normand, K.; Raghavachari, A.; Rendell, J. C.; Burant, S. S.; Iyengar, J.; Tomasi, M.; Cossi, N.; Rega, J. M.; Millam, M.; Klene, J. E.; Knox, J. B.; Cross, V.; Bakken, C.; Adamo, J.; Jaramillo, R.; Gomperts, R. E.; Stratmann, O.; Yazyev, A. J.; Austin, R.; Cammi, C.; Pomelli, J. W.; Ochterski, R. L.; Martin, K.; Morokuma, V. G.; Zakrzewski, G. A.; Voth, P.; Salvador, J. J.; Dannenberg, S.; Dapprich, A. D.; Daniels, Ö.; Farkas, J. B.; Foresman, J. V.; Ortiz, J.; Cioslowski, and D. J. Fox, Gaussian, Inc., Wallingford CT, 2009

18. Sanner, M. F. Python: a programming language for software integration and development, J Mol Graph Model, 1999, 17, 57-61, DOI: 10.1016/S1093-3263(99)99999-0.

19. Forli, S.; Huey, R.; Pique, M. E.; Sanner, M. F.; Goodsell, D. S.; Olson, A. J.; Computational protein-ligand docking and virtual drug screening with the AutoDock suite. Nature protocols, 2016, 11, 905-919, DOI: 10.1038/nprot.2016.051. 
20. Rose, P. W.; Prlic, A.; Bi, C.; Bluhm, W. F.; Christie, C. H.; Dutta, S.; Green, R. K.; Goodsell, D. S.; Westbrook, J. D.; Woo1, J.; Young, J.; Zardecki, C.; Berman, H. M.; Bourne, P. H.; Burley, S. K. The RCSB Protein Data Bank: views of structural biology for basic and applied research and education. Nucl Acids Res, 2015, 43, 345-356, DOI: 10.1093/nar/gku1214.

21. Cowan-Jacob, S. W.; Fendrich, G.; Floersheimer, A.; Furet, P.; Liebetanz, J.; Rummel, G.; Rheinberger, P.; Centeleghe, M.; Fabbro, D.; Manley, P. W. Structural biology contributions to the discovery of drugs to treat chronic myelogenous leukaemia. Biological Crystallography 2007, 63, 80-93, DOI: 10.1107/S0907444906047287.

22. Kaplan W.; Littlejohn, T. G. Swiss-PDB Viewer (Deep View). Briefings in Bioinformatics, 2001, 2, 195-197, DOI: https://doi.org/10.1093/bib/2.2.195.

23. Morris, G. M.; Goodsell, D. S; Halliday, R. S.; Huey, R.; Hart, W. E.; Belew, R. K.; Olson, A, J. Automated docking using a Lamarckian genetic algorithm and an empirical binding free energy function. J Comp Chem, 1998, 19, 1639-1662, DOI: 10.1002/(SICI)1096-987X(19981115)19:14<1639::AID-JCC10>3.0.CO;2-B.

24. Gallardo, S.; Ocampo, A. L.; Contreras, C. A.; Chacón, L. Synthesis and Docking Studies of the Novel N-(2,2-Di(1H-pyrrol-2-yl)ethyl)adamantane-1-carboxamide, a Potential 11 $\beta$-HSD1 Inhibitor. Journal of Chemistry Hindawi, 2014, 1-5, DOI:10.1155/2014/294246

25. Triballeau, N.; Acher, F.; Brabet, I.; Pin, J. P.; Bertrand, H. O. Virtual Screening Workflow Development Guided by the "Receiver Operating Characteristic" Curve Approach. Application to High-Throughput Docking on Metabotropic Glutamate Receptor Subtype 4. J Med Chem, 2005, 48, 2534-2547, DOI: 10.1021/jm049092j.

26. Tiwari, A.; Panigrahi, S. K. HBAT: A Complete Package for Analysing Strong and Weak Hydrogen Bonds in Macromolecular Crystal Structures. In Silico Biology, 2007; 6; 651-661, DOI: content.iospress.com/articles/in-silico-biology/isb00337

27. Lavecchia, A. Machine-learning approaches in drug discovery: Methods and applications. Drug Discov Today, 2014, 20, 318-331, DOI:10.1016/ j.drudis.2014.10.012

28. Ghaaliq, A.; McCluskey, A. Clinical tests: sensitivity and specificity. Continuing Education in Anaesthesia, Critical Care \& Pain. 2008; 8; 221-223, DOI: 10.1093/bjaceaccp/mkn041

29. Auffinger, P.; Hays, F. A.; Westhof, E.; Shing Ho P. Halogen bonds in biological molecules. Proc Natl Acad Sci USA, 2004; 101, 16789-16794, DOI: 10.1073/pnas.0407607101.

30. Regier, A.; Khuu, P.; Oishi, K.; Shing Ho P. Halogen bonds as orthogonal molecular interactions to hydrogen bonds. Nat Chem, 2009; 1; 74-79, DOI: 10.1038/nchem.112.

31. Lu, X.; Wang, Y.; Zhu, W. Nonbonding interactions of organic halogens in biological systems: implications for drug discovery and biomolecular design. Phys Chem Chem Phys, 2010, 12, 4543-04551, DOI: 10.1039/B926326H.

32. Sirimulla, S.; Bailey, J. B.; Vegesna, R.; Narayan, M. Halogen Interactions in Protein-Ligand Complexes: Implications of Halogen Bonding for Rational Drug Design. J Chem Inf Model, 2013, 53, 2781- 2791, DOI: 10.1021/ci400257k.

33. Kortagere, S.; Ekins, S.; Welsh, W. J. Halogenated ligands and their interactions with amino acids: implications for structure-activity and structure-toxicity relationships. J Mol Graph Model, 2008, 27, 170177, DOI: https://doi.org/10.1016/j.jmgm.2008.04.001.

34. Cavallo, G.; Metrangolo, P.; Milani, R.; Pilati, T.; Priimagi, A.; Resnati, G.; Terraneo, G. The Halogen Bond. Chem Rev, 2016, 116, 2478-2601, DOI 10.1021/acs.chemrev.5b00484.

35. Koebel, M. R.; Schmadeke, G.; Posner, R. G.; Sirimulla, S. AutoDock VinaXB: implementation of XBSF, new empirical halogen bond scoring function, into AutoDock Vina. Journal of Cheminformatics, 2016, 8-27, DOI: https://doi.org/10.1186/s13321-016-0139-1.

36. Kurczab, R. The evaluation of QM/MM-driven molecular docking combined with MM/GBSA calculations as a halogen-bond scoring strategy. Acta Crystallographica, 2017, B73, 188-194, DOI: 10.1107/S205252061700138X.

(C) 2017 by the authors. Submitted for possible open access publication under the terms and conditions of the Creative Commons Attribution (CC BY) license (http://creativecommons.org/licenses/by/4.0/). 